\title{
Early iron overload in beta-thalassaemia major: when to start chelation therapy?
}

\author{
S FARGION, M T TADDEI, V GABUTTI, A PIGA, A DI PALMA, L CAPRA, \\ G FONTANELLI, AND A AVANZINI \\ Department of Clinical Medicine III, University of Milan; Department of Clinical Paediatrics, \\ University of Torin; Division of Paediatrics, Ospedale S Anna, Ferrara; Cattedra di Puericultura, Milan
}

SUMMARY Twenty-eight children with $\beta$-thalassaemia major aged between 11 and 48 months were given intensive transfusions. Serum iron, transferrin saturation, serum ferritin, non-transferrin iron, and subcutaneous desferrioxamine-induced urinary iron excretion were measured. The results showed that even children with a limited number of transfusions had severe iron overload as indicated, in particular, by the raised serum ferritin levels and the high excretion rates after subcutaneous infusion of desferrioxamine. The desferrioxamine test was useful, even in very young children, in assessing response to chelation therapy thus enabling such treatment to be started early to prevent harm from iron overload.

Severe iron overload develops progressively in patients with transfusion-dependent homozygous $\beta$-thalassaemia, so that there is a need for continuous chelation therapy. The recent use of subcutaneous desferrioxamine infusion now enables chelation therapy to be started early even though its effectiveness in preventing toxic iron accumulation in $\beta$-thalassaemia major children still has to be proved. ${ }^{1-7}$

The purpose of this work was to study serum iron, transferrin saturation, serum ferritin, the non-specific iron fraction, ${ }^{8}$ and urinary iron excretion in polytransfused patients with $\beta$ thalassaemia major, aged between 11 and 48 months, before they were started on chelation therapy, in order to assess at what age iron overload and early signs of iron toxicity develop and how soon chelation therapy should be started.

\section{Patients}

Twenty-eight children with $\beta$-thalassaemia major, aged between 11 and 48 months, not yet given chelation therapy, were studied. Each was given regular intensive transfusion, starting at age 6-12 months. The annual mean $\mathrm{Hb}$ level was higher than $12.9 \mathrm{~g} / \mathrm{dl}$ (Table 1). None had been splenectomised. Beta-thalassaemia major was diagnosed by routine tests, by the degree of anaemia before blood transfusion, and by the parents' history. On the hypothesis that the patients had vitamin C deficiency (we did not have the facilities to measure levels of vitamin C), each child was given $100 \mathrm{mg}$ ascorbic acid by mouth daily, for a week, before the desferrioxamine (Desferal) test. In the test, desferrioxamine was given by slow ( 8 hours) subcutaneous infusion: first $20 \mathrm{mg} / \mathrm{kg}$ for 3 days and then $40 \mathrm{mg} / \mathrm{kg}$ for 3 days. Samples of urine were collected for 3 days and the daily average urinary iron excretion rate was calculated.

\section{Methods}

All serum samples were obtained before vitamin $C$ administration for the desferrioxamine test was started. To avoid iron contamination disposable iron-free equipment was used throughout the study. All glassware was pretreated for 6 hours in $2 \mathrm{~N}$ hydrochloric acid solution and rinsed several times in iron-free distilled water.

Levels of serum iron and total iron binding capacity were determined by colorimetric analysis, as recommended by ICSH. ${ }^{9}$ Latent iron binding capacity was measured with a saturated solution

Table 1 Annual mean $\mathrm{Hb}$ levels (mean $\pm S D$ ) maintained by transfusion in thalassaemia major children

\begin{tabular}{lcl}
\hline Ages (months) & Number of children & Haemoglobin $(\mathrm{g} / \mathrm{dl})$ \\
\hline $11-24$ & 7 & $13 \cdot 3 \pm 0 \cdot 4$ \\
$25-36$ & 8 & $13 \cdot 6 \pm 0 \cdot 6$ \\
$37-48$ & 13 & $12 \cdot 9 \pm 1 \cdot 0$ \\
\hline
\end{tabular}


containing a volume of ${ }^{59} \mathrm{FeCl}_{2}$ solution sufficient to give about 10000 counts $/ \mathrm{ml}$ per minute in the final solution, as described by ICSH. ${ }^{10}$ Serum ferritin was measured by a two-site immunoradiometric assay (Ramco). The sera containing the highest serum ferritin concentrations had to be diluted $1: 20$.

Unbound iron was measured in duplicate serum samples using the method of Hershko et al. ${ }^{8}$ All sera were obtained from patients before being given iron chelation therapy for 3 days. Briefly, $1 \mathrm{ml}$ of serum was mixed with $0.5 \mathrm{ml}$ of $\mathrm{pH} 7.45$ buffer containing $5 \mathrm{mmol} / 1$ tris and $0.16 \mathrm{~mol} / 1$ sodium

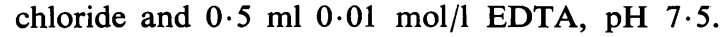
The mixture was incubated at room temperature for 10 minutes.

The solution was then placed in a CF 25 Amicon filter cone (Amicon Corporation, Lexington, Massachussetts) and centıifuged at $400 \times g$ for 20 min. The CF 25 Amicon filter cones retain $95 \%$ of molecules with molecular weight greater than 25000 . About $1 \mathrm{ml}$ of filtrate was obtained from each sample. Filtrate iron concentration was measured by atomic absorption spectroscopy.

Before use, the filters were soaked in EDTA for 2 hours in order to remove any iron contamination. Urinary iron excretion was evaluated by atomic absorption spectroscopy too. Red cells indices were determined in a Coulter electronic cell counter.
Osmotic fragility was measured by adding hypotonic $\Omega$ saline buffered to $\mathrm{pH} 7.4$ and haemolysis was read photoelectrically.

$\mathrm{Hb} \mathrm{A}_{2}$ was quantitated by DEAE-cellulose chro- $\stackrel{\overrightarrow{\vec{S}^{+}}}{\vec{\theta}}$ matography ${ }^{11}$ and $\mathrm{Hb} \mathrm{F}$ by alkali denaturation. ${ }^{12}$

Statistical methods. The coefficient correlation (r) $\frac{\overline{\frac{D}{5}}}{\frac{2}{\alpha}}$ between two independent variables was calculated.

\section{Results}

The details of all the patients, their ages, their ages at $\overrightarrow{\vec{H}}$ the first blood transfusion, the total amount of ${ }_{\sigma}^{\omega}$ blood transfused, and the levels of iron at the time of the study are shown in Table 2.

Mean values for serum iron, transferrin saturation, $y$ serum ferritin, and urinary iron excretion are shown $\vec{N}$ in Table 3. All levels were high, even in the youngest $c 0$ group of children. Desferrioxamine-induced urinary $\mathbb{C}_{0}$ iron excretion after a dose of $20 \mathrm{mg} / \mathrm{kg}$ resulted in 을 high levels only in children between 37 and 48 months of age, but after a dose of $40 \mathrm{mg} / \mathrm{kg}$ the levels were very high in all children. There was no correlation between serum ferritin and the age of the $\frac{\mathbb{}}{3}$ patients. There was a weak correlation between desferrioxamine-induced urinary iron excretion $\left(20^{-}\right.$ $\mathrm{mg} / \mathrm{kg})$ and the age of patients $(\mathrm{P}<0.05)$, but not $\overrightarrow{\mathrm{e}}$ after a dose of $40 \mathrm{mg} / \mathrm{kg}$.

Table 2 Data for the 28 children

\begin{tabular}{|c|c|c|c|c|c|c|c|c|}
\hline \multirow{3}{*}{ Case } & \multirow{3}{*}{$\begin{array}{l}\text { Age } \\
\text { (months) }\end{array}$} & \multirow{3}{*}{$\begin{array}{l}\text { Age at which } \\
\text { frst transfusion } \\
\text { given (months) }\end{array}$} & \multirow{3}{*}{$\begin{array}{l}\text { Total blood } \\
\text { transfused } \\
(\mathrm{ml})\end{array}$} & \multicolumn{5}{|c|}{ Post-transfusion values } \\
\hline & & & & \multirow{2}{*}{$\begin{array}{l}\text { Serum } \\
\text { iron } \\
(\mu \mathrm{g} / 100 \mathrm{ml})\end{array}$} & \multirow{2}{*}{$\begin{array}{l}\text { Transferrin } \\
\text { saturation } \\
(\%)\end{array}$} & \multirow{2}{*}{$\begin{array}{l}\text { Ferritin } \\
(n g / m l)\end{array}$} & \multicolumn{2}{|c|}{ Urinary iron excretion $(\mathrm{mg} / 24 \mathrm{~h})$} \\
\hline & & & & & & & $\begin{array}{l}\text { Desferrioxamine } \\
(20 \mathrm{mg} / \mathrm{kg})\end{array}$ & $\begin{array}{l}\text { Desferrioxamine } \\
(40 \mathrm{mg} / \mathrm{kg})\end{array}$ \\
\hline 1 & 11 & 11 & 544 & 244 & 100 & 730 & & \\
\hline 2 & 17 & 2 & 2440 & 244 & 100 & 3300 & $2 \cdot 5$ & $10 \cdot 5$ \\
\hline 3 & 17 & 2 & 2632 & 211 & 85 & 1480 & & \\
\hline 4 & 18 & 8 & 3080 & 197 & & 1440 & & \\
\hline 5 & 19 & 6 & 2800 & 57 & 36 & 660 & $2 \cdot 4$ & $4 \cdot 6$ \\
\hline 6 & 22 & 2 & 2928 & 174 & 51 & 4500 & & \\
\hline 7 & 24 & 5 & 2688 & 255 & 100 & 4000 & 2 & $4 \cdot 1$ \\
\hline 8 & 26 & 8 & 3400 & 215 & 100 & 2100 & $4 \cdot 2$ & $7 \cdot 1$ \\
\hline 9 & 26 & 3 & 4192 & 155 & 49 & 1700 & 0.9 & $1 \cdot 6$ \\
\hline 10 & 28 & 4 & 4216 & 216 & 100 & 2900 & 1 & $8 \cdot 7$ \\
\hline 11 & 28 & 4 & 4424 & 255 & 100 & 2600 & & \\
\hline 12 & 29 & 6 & 2584 & 208 & 100 & 1300 & $3 \cdot 1$ & $4 \cdot 2$ \\
\hline 13 & 32 & 6 & 3722 & 107 & 58 & 1500 & 1 & 3 \\
\hline 14 & 33 & 3 & 6480 & 234 & 100 & 2500 & & \\
\hline 15 & 36 & 11 & 5760 & 300 & 100 & 1320 & & \\
\hline 16 & 37 & 12 & 4250 & 205 & 89 & 1320 & $3 \cdot 7$ & 7 \\
\hline 17 & 38 & 6 & 8184 & 175 & 50 & 4000 & $5 \cdot 9$ & $8 \cdot 5$ \\
\hline 18 & 39 & 7 & 5920 & 155 & 47 & 1800 & & \\
\hline 19 & 41 & 11 & 6376 & 188 & 88 & 2900 & $2 \cdot 8$ & 12 \\
\hline 20 & 44 & 6 & 10176 & 222 & 72 & 3300 & $3 \cdot 2$ & $10 \cdot 7$ \\
\hline 21 & 45 & 6 & 5520 & 155 & 71 & 1040 & $1 \cdot 2$ & $2 \cdot 7$ \\
\hline 22 & 47 & 24 & 5184 & 174 & 87 & 2250 & $6 \cdot 1$ & $6 \cdot 1$ \\
\hline 23 & 47 & 5 & 10320 & & & 4200 & $5 \cdot 7$ & 8.9 \\
\hline 24 & 48 & 14 & 10064 & 208 & 100 & 4300 & $6 \cdot 5$ & $16 \cdot 3$ \\
\hline 25 & $4 ?$ & 16 & 8824 & 175 & 100 & 2700 & $2 \cdot 1$ & $10 \cdot 5$ \\
\hline 26 & 44 & 3 & 12000 & 231 & 100 & 4300 & & \\
\hline 27 & 48 & 4 & 10400 & 155 & 74 & 2600 & $6 \cdot 2$ & $9 \cdot 3$ \\
\hline 28 & 48 & 11 & 9120 & 247 & 100 & 2100 & 6 & 7.4 \\
\hline
\end{tabular}


Table 3 Mean serum iron, transferrin saturation, serum ferritin, and urinary excretion in patients with $\beta$-thalassaemia major (mean $\pm S D)$

\begin{tabular}{|c|c|c|c|c|c|c|}
\hline \multirow{2}{*}{$\begin{array}{l}\text { Age } \\
\text { (months) }\end{array}$} & \multirow{2}{*}{$\begin{array}{l}\text { Number of } \\
\text { children }\end{array}$} & \multirow{2}{*}{$\begin{array}{l}\text { Serum iron } \\
(\mu \mathrm{g} / 100 \mathrm{ml})\end{array}$} & \multirow{2}{*}{$\begin{array}{l}\text { Transferrin } \\
\text { saturation } \\
(\%)\end{array}$} & \multirow{2}{*}{$\begin{array}{l}\text { Ferritin } \\
(n g / m l)\end{array}$} & \multicolumn{2}{|c|}{ Urinary iron excretion $(\mathrm{mg} / 24 \mathrm{~h})$} \\
\hline & & & & & $\begin{array}{l}\text { Desferrioxamine } \\
(20 \mathrm{mg} / \mathrm{kg})\end{array}$ & $\begin{array}{l}\text { Desferrioxamine } \\
(40 \mathrm{mg} / \mathrm{kg})\end{array}$ \\
\hline $\begin{array}{l}11-24 \\
25-36 \\
37-48\end{array}$ & $\begin{array}{r}7 \\
8 \\
13\end{array}$ & $\begin{array}{l}197 \pm 75 \\
211 \pm 59 \\
191 \pm 31\end{array}$ & $\begin{array}{l}79 \pm 28 \\
88 \pm 22 \\
81 \pm 19\end{array}$ & $\begin{array}{l}2301 \pm 1596 \\
1990 \pm 623 \\
2831 \pm 1128\end{array}$ & $\begin{array}{l}2 \cdot 3 \pm 0 \cdot 3 * \\
2 \cdot 2 \pm 1 \cdot 8 \dagger \\
4 \cdot 5 \pm 1 \cdot 9 \ddagger\end{array}$ & $\begin{array}{l}6.4 \pm 3 \cdot 6 \\
4 \cdot 7 \pm 3 \cdot 0 \\
9 \cdot 0 \pm 3 \cdot 5\end{array}$ \\
\hline
\end{tabular}

* Performed in 3 ; tperformed in 5 ; łperformed in 11 .

There was a significant correlation between the amount of blood transfused and the serum ferritin level $(\mathrm{P}<0.01)$ (Fig. 1) and between the amount of blood transfused and desferrioxamine-induced urinary iron excretion for both doses $(P<0.01)$ (Fig. 2). A highly significant correlation between

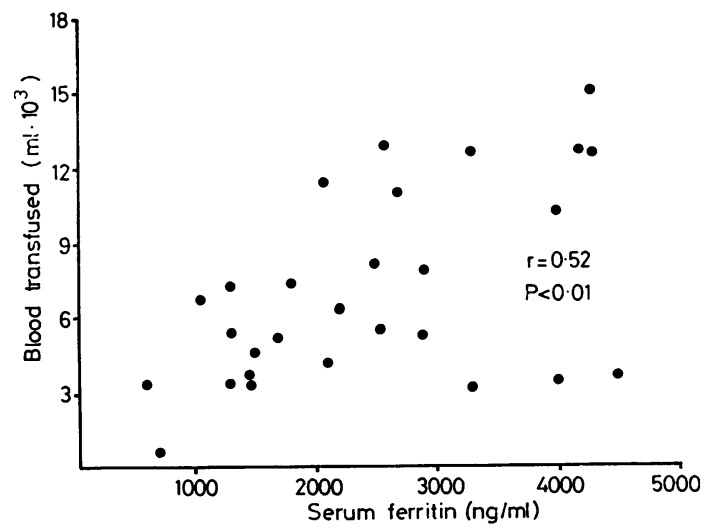

Fig. 1 Correlation between serum ferritin and amount of blood transfused. serum ferritin and $40 \mathrm{mg} / \mathrm{kg}$ desferrioxamineinduced urinary iron excretion rate $(\mathrm{P}<0.01)$ was observed, but not after $20 \mathrm{mg} / \mathrm{kg}$ (Fig. 3).

Non-transferrin iron was detected in 11 of the 27 patients, being present in those in whom the transferrins were completely iron saturated (Table 4). The non-specific iron concentrations were in the range of 9 and $28 \mu \mathrm{g} / \mathrm{dl}$.

There was no correlation between non-specific iron and either serum ferritin or desferrioxamineinduced iron excretion.

\section{Discussion}

Our findings show that there can be severe iron overload in children younger than 4 years old. The intensive transfusion regimens to which the children were subjected led us to assume that the major endogenous factor influencing iron absorption, erythropoiesis, is minimal in such young children, so that roughly the entire iron load could be attributed to the blood received. ${ }^{13}$ This is confirmed by the significant correlation between serum ferritin, which reflects iron stored, and the amount of blood

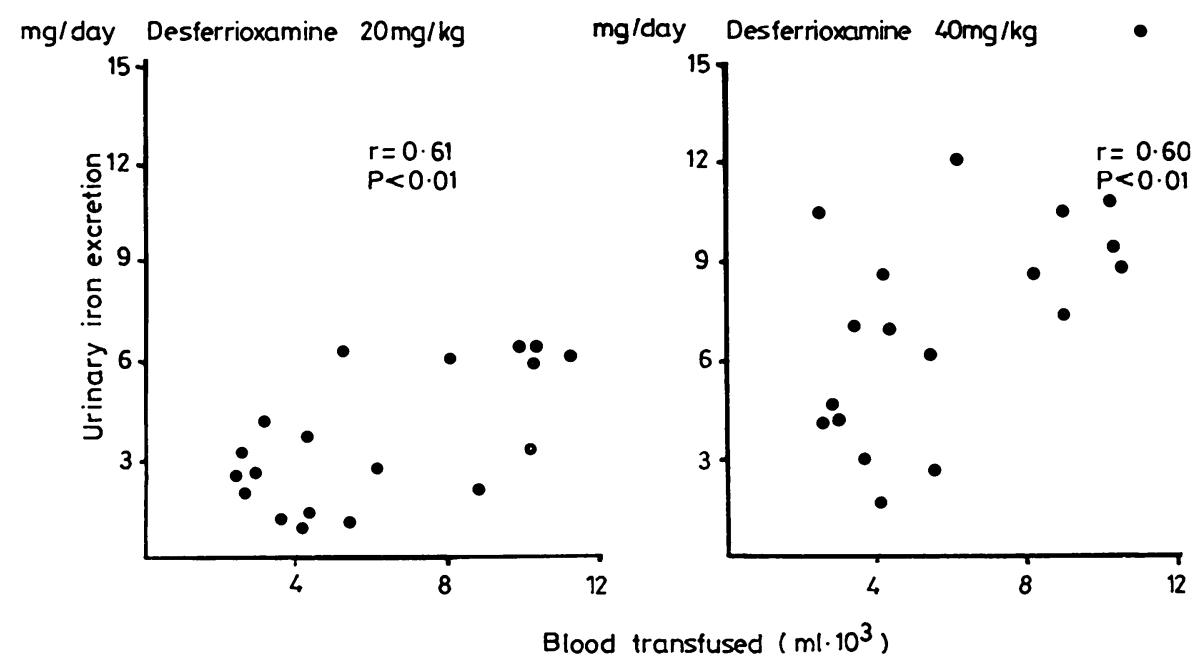

Fig. 2 Correlation between blood transfused and desferrioxamine-induced urinary iron excretion. 
$\mathrm{mg} /$ day Desferrioxamine $20 \mathrm{mg} / \mathrm{kg}$

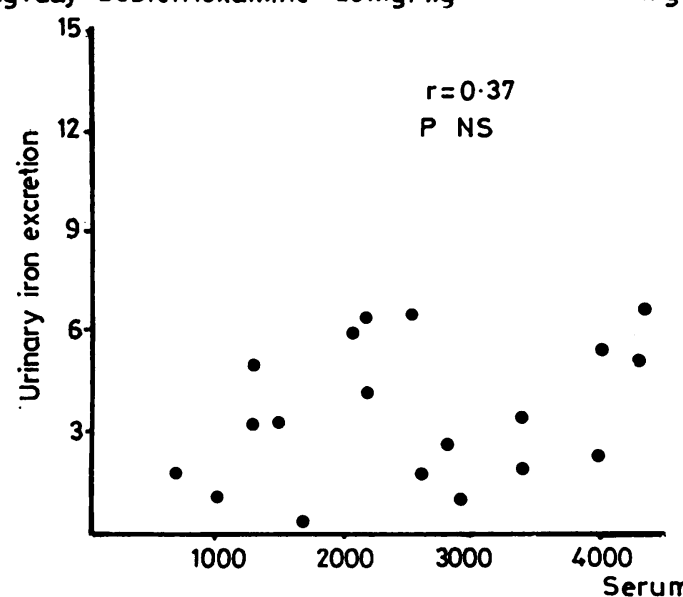

$\mathrm{mg} /$ day Desferrioxamine $40 \mathrm{mg} / \mathrm{kg}$

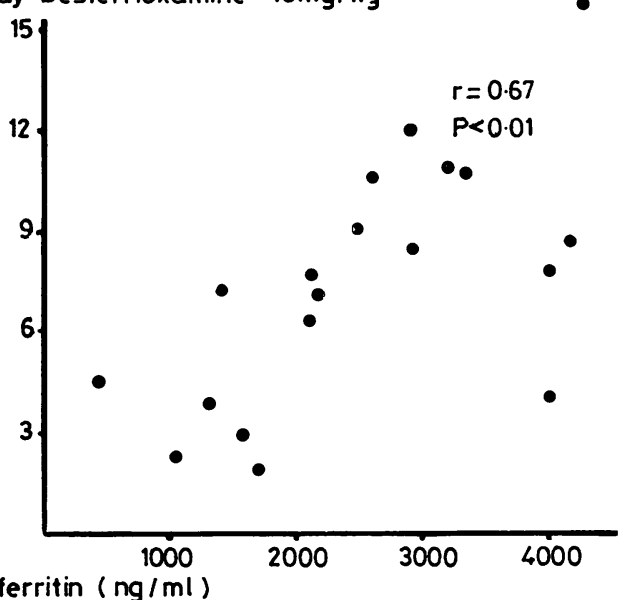

Fig. 3 Correlation between serum ferritin and desferrioxamine-induced urinary iron excretion.

Table 4 Non-transferrin iron in patients with $\beta$ thalassaemia major

\begin{tabular}{lll}
\hline Age (months) & Number of children & $\begin{array}{l}\text { Patients with non- } \\
\text { transferrin iron }\end{array}$ \\
\hline $11-24$ & $7^{*}$ & 1 \\
$25-36$ & 8 & 4 \\
$37-48$ & 13 & 6 \\
\hline
\end{tabular}

*Not performed in one patient.

transfused. The high correlation between desferrioxamine-induced urinary iron excretion (after either 20 or $40 \mathrm{mg} / \mathrm{kg}$ ), which reflects the chelatable iron pool, and the amount of blood transfused also supports this view. Moreover, the positive relationship between serum ferritin and urinary iron excretion after desferrioxamine confirms that both these parameters are directly related to iron load.

It should be noted that transferrin saturation, serum ferritin, and urinary iron excretion after subcutaneous infusion of desferrioxamine (particularly after $40 \mathrm{mg} / \mathrm{kg}$ ) were greatly raised in very young children. Some of them even showed iron overload after only a few blood units and we feel that an early start of chelation therapy in such children may delay the iron load-induced tissue damage (as was shown by Modell ${ }^{15}$ ). The finding of non-specific iron in children younger than 4 years extends Hershko's observations. He found nontransferrin iron, considered to be an index of iron toxicity, in patients with $\beta$-thalassaemia major and intermedia aged between 6 and 30 years who had secondary haemochromatosis. ${ }^{8}$ Similarly, Batey et al. ${ }^{14}$ recently found non-transferrin iron in the sera of patients with severe iron overload caused by idiopathic haemochromatosis.

The presence of non-transferrin iron in the sera $\stackrel{\oplus}{3}$ of these patients confirms that iron overload and $\mathbb{D}$ iron toxicity develop very early in children with $\vec{\circ}$ $\beta$-thalassaemia major. The lack of correlatiog between non-transferrin iron and either serum? ferritin or urinary iron excretion may be due to the fact that there were few patients studied or that the iron overload was at an early stage.

Our findings show that $\beta$-thalassaemia major ${ }_{0}$ children, even those younger than 2 years, can have $\stackrel{\mathbb{Q}}{\mathscr{Q}}$ a severe iron overload and that regular subcutaneous $\overrightarrow{\vec{A}}$ infusion of desferrioxamine could greatly improve $\frac{0}{3}$ survival and should be started as soon as possiblethat is from about the 3rd transfusion-according to the response of the patient to the desferrioxamine test performed with both doses ( 20 and $40 \mathrm{mg} / \mathrm{kg}$ a day).

We thank Dr G Masera, Dr C Vullo, Dr G Fiorelli, and Dr M Miniero for advice and their methodological contribution.

\section{References}

1 Propper R D, Shurin S B, Nathan D G. Reassessment of the use of desferrioxamine $\mathrm{B}$ in iron overload. $N$ Engl $J$ o Med 1976; 294: 1421-3.

2 Modell C B, Beck J. Longterm desferrioxamine therapy in $N$ thalassaemia. Ann NY Acad Sci 1974; 232: 201-10.

3 Barry M, Flynn D M, Letsky E A, Risdon R A. Longterm $\omega$ chelation therapy in thalassaemia major: effect on liver iron concentration, liver histology, and clinical progress. Br Med J 1974; ii: 16-20.

4 Propper R D, Cooper B, Rufo R R, et al. Continuous subcutaneous administration of deferoxamine in patients with iron overload. $N$ Engl J Med 1977; 297: 418-23. 
5 Letsky E A. A controlled trial of long-term chelation therapy in homozygous beta-thalassaemia. Birth Defects 1976; 12: No 8, 31-41.

6 Pippard M J, Letsky E A, Callender S T, Weatherall D J. Prevention of iron loading in transfusion-dependent thalassaemia. Lancet 1978; i: 1178-81.

7 Hoffbrand A V, Gorman A, Laulicht M, et al. Improvement in iron status and liver function in patients with transfusional iron overload with long-term subcutaneous desferrioxamine. Lancet 1979; i: 947-9.

8 Hershko C, Graham G, Bates G W, Rachmilewits E A. Non-specific serum iron in thalassaemia: an abnormal serum iron fraction of potential toxicity. $\mathrm{Br} \mathrm{J} \mathrm{Haematol}$ 1978; 40: 255-63.

- International Committee for Standardisation in Haematology. Recommendations for measurement of serum iron in human blood. Br J Haematol 1978; 38: 291-4.

10 International Committee for Standardisation in Haematology. The measurement of total and unsaturated ironbinding capacity in serum. $\mathrm{Br} J$ Haematol 1978; 38: 281-90.

11 Huisman T H J, Schroeder W A, Brodie A N, Mayson S M, Jackway J. Microchromatography of hemoglobins. II. A simplified procedure for the determination of hemoglobin $A_{2}$. J Lab Clin Med 1975; 86: 700-2.

12 Singer K, Chernoff A I, Singer L. Studies on abnormal hemoglobins. I. Their demonstration in sickle cell anemia and other hematologic disorders by means of alkali denaturation. Blood 1951 ; 6: 413-28.

13 Propper R D, Button L N, Nathan D G. New approaches to the transfusion management of thalassemia. Blood 1980; 55: 55-60.

14 Batey R G, Lai Chung Fong P, Shamir S, Sherlock S. A non-transferrin-bound serum iron in idiopathic hemochromatosis. Dig Dis Sci 1980; 25: 340-6.

15 Modell B, Letsky E A, Flynn D M, Peto R, Weatherall $D$ J. Survival and desferrioxamine in thalassaemia major. $\mathrm{Br}$ Med J 1982; 284: 1081-4.

Correspondence to Professor G Masera, Clinica Pediatrica 'G e D de Marchi', via Commenda 9, 20122 Milano, Italy.

Received 21 June 1982 